\title{
ROLE OF INDIGENOUS WISDOM IN FOOD \\ SELECTION: STUDY OF STUDENTS NUTRITIONAL \\ STATUS OF FOOD NUTRITION PROGRAM-WIDYA MANDALA SURABAYA CATHOLIC UNIVERSITY
}

by Anna Ingani Widjajaseputra

FILE

TIME SUBMITTED

SUBMISSION ID
OK_2-ROLE_OF_INDIGENOUS_WISDOM 26-OCT-2020 12:59PM (UTC+0700) 1426707925
INGANI.PDF (298.3K)

WORD COUNT

3592

CHARACTER COUNT 19219 
"B74IJFNPH13"

6

ROLE OF INDIGENOUS WISDOM IN FOOD SELECTION: STUDY OF STUDENTS

NUTRITIONAL STATUS OF FOOD NUTRITION PROGRAM-WIDYA MANDALA SURABAYA CATHOLIC UNIVERSITY

\author{
11 \\ AnnaIngani Widjajaseputra*, Theresia Endang Widoeri Widyastuti, Maria Matoetina Suprijono and \\ $1 \quad$ Chatarina Yayuk Trisnawati \\ Faculty of Agricultural Technology- WIDYA MANDALA SURABAYA CATHOLIC UNIVERSITY
}

\begin{abstract}
Students need an adequate nutrients that can improve and maintain their physical endurance, mental and cognitive. Therefore, it is important to study the nutritional status of the students. The aim of this research is to obtain comprehensive information about the students nutritional status and its relation to the internal and external factors. This study used purposive sampling method to study 94 students of Food Nutrition program of Widya Mandala Surabaya Catholic University, aged around 20 years old. The nutritional status determined by anthropometric method and the influenced factors collected by questionnaire and recall diet. This study showed more than $60 \%$ of respondents have healthy nutritional status criteria which was based on the level of nutrient consumption fulfillment of energy, protein, vitamin $\mathrm{A}$ and $\mathrm{Fe}$ (iron). The levels of fulfillment were $72 \%, 98 \%, 388 \%$ and $92 \%$ respectively. The data showed that most of nutritional fulfillment has been supported by the eating habits of the respondents $(70.97 \%)$ who enjoy light meal. The food selection of respondents was based on preference of local food and light meal $(100 \%$ of the respondents) and it was not so depend on nutritional knowledge.
\end{abstract}

Key words: indigenous wisdom, food selection, eating habit, nutritional status

\title{
INTRODUCTION
}

Nutritional status indicated that one's health is conditioned by the consumed nutrients both quantitatively and qualitatively, as well as the ability of the body to use these nutrients to meet metabolic demands. A self-reported questionnaire was administered to 94 students, ranging in age about 19-20 years old. Nutritional need is to meet the needs of high physiological development, and to support the daily activities as student. The nutrients satiety will determine the ability to learn, working productivity, and health of students (Soetardjo, 2011b). Data of Basic Health Research of year 2010 showed that the nutritional status of adults (over 18 years old) is dominated by the problem of obesity $(21.7 \%)$, with rates of obesity in women $(26.9 \%)$ than males $(16.3 \%)$ of the well-educated and higher economic status of urban population in Indonesia. The prevalence of obesity in East Java is 20.6\% (Indonesia Ministry of Health, 2010).

* Corresponding author; E-mail: ingani9456@yahoo.com 
Adequate nutrients achievement can improve morale and physiological abilities of students in meeting the demands of physical endurance, mental and cognitive for studying both through lectures and practical work. One method to determine the nutritional status of students is the anthropometric assessment- the Body Mass Index (BMI). The method is very simple which was selected as one of the practical courses to aid for understanding of nutritional status, but it has been less successful because the data are less comprehensive. Various internal and external factors affected the nutritional status of students such as the interest, knowledge, perception and funds for providing healthy foods. Relationships between factors were necessary to be studied more in depth because it can affect the nutritional status of subjects. For example, Shiwaku et al. (2004) found that the relationship between abdominal fat mass and BMI is specific for each ethnic. Universal BMI standards are not appropriate for Asian societies such as the Japanese and Mongolian because of the different life style, characters and perception. In addition, the accuracy of BMI to diagnose obesity is limited, particularly for individuals who are in the intermediate range of BMI (Abel Romero-Corral et al., 2008). Therefore, in this study, measurement of BMI was equipped with a measuring percent body fat and water, recall of food consumption, as well as extracting the various internal and external factors are needed. Therefore, it is necessary to study the nutritional status which is related to the amount of adult nutritional intake, eating habits and nutritional knowledge of the respondents, in order to obtain more comprehensive evaluation methods that will improve the nutritional status evaluation as a material input of food nutrition courses.

There are many kinds of Indonesian cuisine, so that Indonesian people could choose the menu to fulfill their nutrition needs. Rice is the staple food in major areas of Indonesia, but it is frequently supplemented by others such as sweet potatoes, cassava, and corn. In Indonesia, where much cassava is being eaten, the sweet potato is being promoted because it is nutritionally better than cassava especially in taste of sweet, sugar content and no glycocyanogen content. Corn should have an important role in Indonesian people's diet, because it supplied substantial amounts of protein and carotene besides the energy content. Mung beans sprouts is the potential source of vitamin $\mathrm{E}$ and dietary fiber, this commodity is used in daily diet of Indonesian people as ingredient of pecel, urap, gado-gado and tahu campur.

Pecel is one kind of Indonesian foods which is consisted of steamed vegetables such as spinach, cabbage and mung bean sprouts.The steamed vegetables is added by special sauces 
which is consisted of blended of fried groundnut, coconut sugar, salt and other spicy. The difference of urap and pecel that urap is mixture of steamed vegetables with spicy shredded coconut without ground nut sauces, Gado-gado's sauces is without cooking lemon's leaves but with ground nut sauce like pecel. Tahu campur is one of popular food from East Java, especially in Surabaya. It's sort of beef soup served with green salad, mung bean sprouts, egg noodle, fried tofu, spiced fried cassava, garlic crackers and the sauce contained black shrimp paste.

The purpose of this research was to achieve more comprehensive nutritional evaluation methods which is related to the amount of adult nutritional intake, eating habits and nutritional knowledge of the respondents

\section{RESEARCH METHODOLOGY}

This study used purposive sampling that participants were selected intentionally, such as students of Food Nutrition Program of even semester 2011/2012. A self-reported questionnaire was administered to 94 students, ranging in age about 19-20 years old.

Data Collecting

The questionnaire was designed to get all the data associated with the internal and external factors which determine nutritional status. Diet recall form of whole nutrient consumption during 3 days in each week was provided by each respondent. Measurement of anthropometric data (BMI, Body fat and Body water) was performed at the laboratory.

Data Processing

Descriptive analysis were carried out on nutrients consumption data, body fat, body water, BMI and nutritional status by calculating the mean and standard deviation so that it was able to predict the center and spreading of the data. Linear regression and correlation analysis were conducted to determine the relationship of BMI and body fat. 


\section{Food Consumption Study}

The monitoring of consumed food was provided during six weeks by using specially design of Food Questionnaire (FQ). The portion of sizes were used in FQ were based on household size such as slice, piece, cup. When natural portion size was being uncertain, so the portion size was declared as small, medium or large. The nutritive and energy values of consumed foods were calculated by using the table of food composition which was issued by Indonesian Ministry of Health of year 1996.

\section{Anthropometric Assessment}

Measurement of weight and height were taken in the morning with respondents were wearing light clothes and without socks and shoes. Weight was determined by using Body Fat/ Hydration- Monitor Scale-model 273867- Kris - Registered Number: AKL-20502111684- Made in China. Height was measured by using a manual stature meter which range until $200 \mathrm{~cm}$. Evaluation of Nutritional Status by Anthropometric assessment - Body Mass Index measurements were facilitated by percent body fat and water, as well as various internal and external factors assessment, such as nutrient consumption, nutritional knowledge, eating habits, nutrient intake level and physical activity.

\section{RESULTS AND DISCUSSION}

Data of this research and general phenomena in Indonesian community showed that healthy nutritional status was not achieved only by meat consuming, but also by consuming of mixture of varieties commodity which are healthy foods such as gado-gado, pecel and tahu campur. Basic consideration of Indonesian community in food selection was influenced by eating habits, available commodities and budget. Fortunately the mixture of the selected foods which is affected by indigenous wisdom gained the increasing of protein content, iron content and vitamin A as supplementation effect. Descriptions of several factors and the relationships between factors are described below.

\section{Relationship between Level of Consumption and Nutritional Status of Respondents}

The data in Table 1 showed the mean height, body weight and the calculated of body mass index (BMI) of 94 respondents ranged from 15.72 to 34.73; with an average BMI of 22.02 
\pm 3.97 was classified in healthy nutritional status. The value of BMI from 18.5 to 25.0 was considered as normal body weight of healthy status. The condition was supported by an adequate level of nutrition consumption, especially the consumption of protein (98\%), vitamin A (388\%) and Fe which has reached an average of $92 \%$ of the nutritional adequacy (Recommended Dietary Allowances-RDA), although the energy of the adequacy of the respondents on average only $72 \%$ RDA (Table 2). This fact can be caused by physical activity most of the respondents (students) can be classified as light activity and many respondents ate snacks during doing activities (Table 5). It should note that the amount consumed food and energy content were not recorded completely. This showed the weakness of recall diet as the method for data collecting, especially in calculating the nutrition value of the food consumption.

Table 1. Anthropometric data of Respondents *)

\begin{tabular}{|l|c|}
\hline \multicolumn{1}{|c|}{ Criteria } & $\begin{array}{c}\text { Mean } \pm \text { standard } \\
\text { deviation }\end{array}$ \\
\hline Body Weight $(\mathrm{kg})$ & $57,83 \pm 14,09$ \\
Height $(\mathrm{cm})$ & $161,4 \pm 8,13$ \\
Body Mass Index & $22,02 \pm 3,97$ \\
\hline
\end{tabular}

Note:*)The number of respondents $(\mathrm{n})=94$ people

Table 2. Nutrient Consumption Assessment

\begin{tabular}{|l|c|c|c|c|}
\hline \multicolumn{1}{|c|}{ Item of measurement } & $\begin{array}{c}\text { Energy } \\
(\mathrm{Cal})\end{array}$ & $\begin{array}{c}\text { Protein } \\
(\mathrm{g})\end{array}$ & $\begin{array}{c}\text { Vitamin A } \\
(\mathrm{RE})\end{array}$ & $\begin{array}{c}\mathrm{Fe} \\
(\mathrm{mg})\end{array}$ \\
\hline Average consumption & 1656 & 56,27 & 2051,54 & 18,32 \\
Nutritional Adequacy & 2303,63 & 56,81 & 524 & 22,82 \\
Nutrient Consumption Level $(\%)$ & 72 & 98 & 388 & 92 \\
\hline
\end{tabular}

Table 3. Nutritional Status of Respondents

\begin{tabular}{|c|l|l|c|c|}
\hline \multirow{2}{*}{ No } & \multicolumn{1}{|c|}{ BMI } & Nutritional Status & \multicolumn{2}{|c|}{$\begin{array}{c}\text { Percentage of Nutritional } \\
\text { Status (\%) }\end{array}$} \\
\cline { 4 - 5 } & & & First week & Sixth week \\
\hline 1. & $<17,0$ & $\begin{array}{c}\text { Chronic Energy } \\
\text { Deficiency }\end{array}$ & 5,32 & 6,38 \\
\hline 2. & $17,0-18,4$ & Unhealthy thin & 9,57 & 10,64 \\
\hline 3. & $18,5-25,0$ & Healthy & 63,83 & 61,70 \\
\hline 4. & $25,1-27,0$ & Unhealthy fat & 8,51 & 7,45 \\
\hline 5. & $>27,0$ & Obesity & 12,77 & 13,83 \\
\hline
\end{tabular}


Based on the classification of Indonesian Ministry of Health, $63.83 \%$ of respondents were classified as healthy, $5.32 \%$ as chronic energy deficiency, $9,57 \%$ as unhealthy thin, $8.51 \%$ as healthy fat, and $12.77 \%$ of respondents were classified as obese. Deviation from the mean of BMI value of the sample showed the presence of some extreme values, such as respondents were classified as negative on very thin (BMI <17.0) to a relatively unhealthy thin $(17.0-18.4)$ and were classified as obese ( BMI> 27.0). Observational data on sixth week showed the change in the direction of the nutritional status of the respondents, by increasing and decreasing of the BMI. Positive changes occurred only among respondents who considered as unhealthy fat (25.1 27.0) were demonstrated by the percentage compared to the data in the 1st week. Based on the results of t-test with $\alpha=0.10$ the data generated nutritional status of respondents in Week 1 and 6 are not significant different statistically, with $t=0.0176$ which is smaller than the $t$ critical region $(\mathrm{t}<-1.645$ or $\mathrm{t}>1.645)$. Based on the data presented in Tables 3 , it was seen that the phenomenon is more than $60 \%$ of respondents who have a healthy nutritional status criteria with BMI 18.5 to 25.0 supported the data in Table 2, the rate of nutrient consumption for energy, protein, vitamin $\mathrm{A}$ and $\mathrm{Fe}$ were $72 \%, 98 \%, 388 \%$ and $92 \%$ respectively. Achievement of the above nutrient consumption maybe partly was caused by indigenous wisdom of Indonesian people in food selection with the main meal of rice commodities, such as supplementation effect on rice and dried fish menu to increase the chemical score of protein, combination of ingredients in tahu campur recipe such as beef soup served with green salad, mung bean sprouts, egg noodle, fried tofu, spiced fried cassava, garlic crackers and the sauce contained black shrimp paste and other selected traditional foods in daily consumption. It is mean that the role of the parent to introduce the eating habits to their children is an important method to gain a good nutritional status.

\section{Relationship between Nutrition Knowledge and Nutritional Status of Respondents}

Nutritional knowledge of respondents indicated that the food selection is based on food preference only $(100 \%)$ and knowledge of required nutrient is based on high school's level $(100 \%)$. Limited nutritional knowledge did not affect the nutritional status, it is related to the phenomena that Nutritional Status of Respondents showed an average BMI $22.02 \pm 3.97$; thus nutritional status of respondents still healthy relatively ( Healthy criteria of BMI is 18.5 to 25.0). The phenomenon was also obtained by Sakamaki et al. (2005) which studied the knowledge of nutrition, healthy eating habits and behavior of the students at the Chinese 
University. In that study, although $85.6 \%$ of the students know the concept of food with balanced nutrition, but only a few students $(7 \%)$ who apply the concept in foods selection on their menu.

\section{Relationships between Body Fat - Water and Eating Habits}

Body Fat of respondents indicated an average of $21.71 \%$ (Table 4) so it was not categorized as obese, because obesity's Body Fat for males $>25 \%$ and women $>35 \%$ (WHO, 1995 in Abel Romero-Corral 2008). Figure 2 shows the relationship between the body fat and BMI. The graph in Figure 2 did not distinguish between male and female respondents which related to unequal amount of them (the male respondents is $24.73 \%$ of 94 persons population). Data percent body water of respondents were on average of $53.97 \%$, it showed no symptoms of abnormal water retention because it is still lower than the average water content of standard body size of $60 \%$ (Wilson et al., 1979). The data make it clear that the food consumption pattern of respondents was correct during six weeks observation.

Table 4. BMI, Body Fat and Body Water of Respondents

\begin{tabular}{|l|c|c|}
\hline \multicolumn{1}{|c|}{ Items of measurement } & First week & Sixth week \\
\hline Average of BMI & $22,02 \pm 3,97$ & $22,01 \pm 4,03$ \\
\hline Average of Body Fat $(\%)$ & $21,71 \pm 6,40$ & $21,70 \pm 6,77$ \\
\hline Average of Body Water $(\%)$ & $53,97 \pm 4,75$ & $53,83 \pm 4,59$ \\
\hline
\end{tabular}

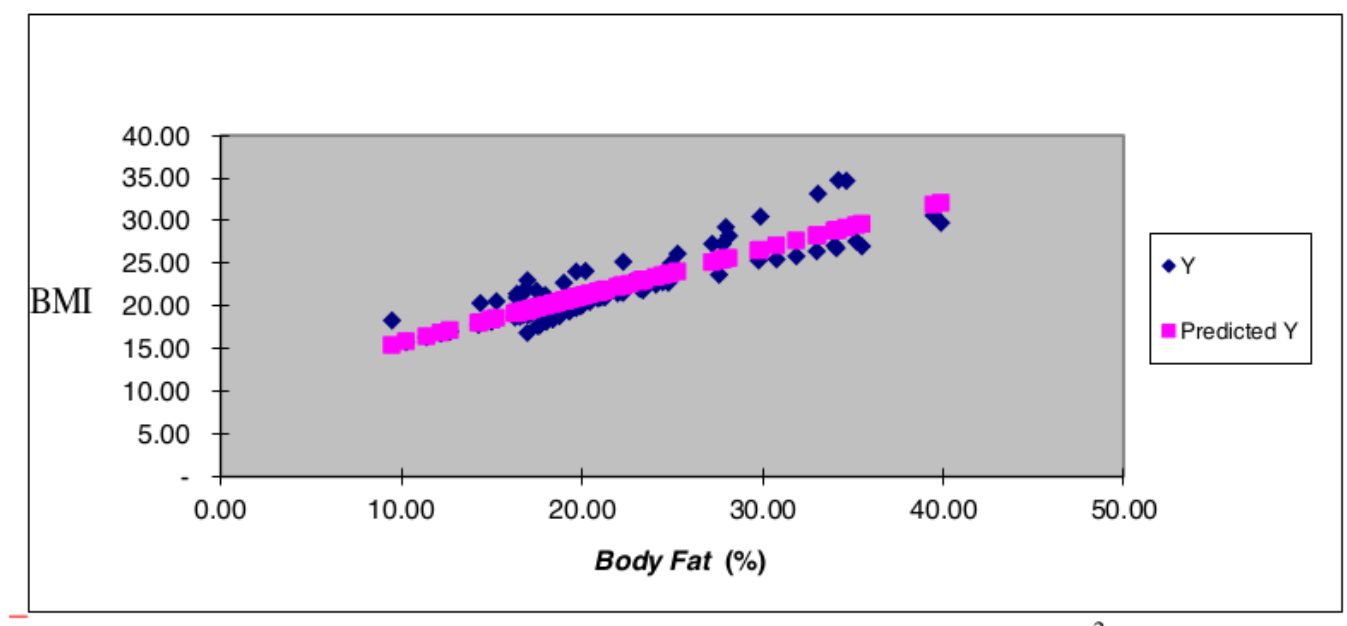

Figure 2. Regression of BMI (Y) dan Body Fat (X) with $\mathrm{R}^{2}=0,78$ 
Table 5. Related Conditions to Eating Habits

\begin{tabular}{|l|l|c|c|c|}
\hline \multirow{2}{*}{ No. } & \multicolumn{1}{|c|}{ Questions } & \multicolumn{3}{|c|}{ Frequency (\%) } \\
\cline { 3 - 5 } & \multicolumn{1}{|c|}{$\begin{array}{c}\text { Always } \\
\text { bo you have breakfast in the morning } \\
\text { before doing activities? }\end{array}$} & 100 & 0 & 0 \\
\hline 2. & $\begin{array}{l}\text { Do you like to eat together (with family } \\
\text { or friends)? }\end{array}$ & 100 & 0 & 0 \\
\hline 3. & $\begin{array}{l}\text { Do you like to eat snacks while doing } \\
\text { certain activities? }\end{array}$ & 70.97 & 29.03 & 0 \\
\hline 4. & Do you like to eat fast food? & 0 & 100 & 0 \\
\hline
\end{tabular}

Based on the questionnaire on Table 5, the data of respondents indicated that respondents have breakfast before doing the activities $(100 \%)$, and like to eat with family and or friends $(100 \%)$. This was due to the students living with their parents $(72.53 \%)$ or relatives $(1.10 \%)$, while $26.37 \%$ of respondents were in lodging. Respondents have a tendency to eat snacks during the activities in criteria "always" (70.97\%) and "sometimes" $(29.03 \%)$. The eating habits of respondents showed they consumed fast food occasionally (100\%). Eating habits of the respondents was strongly influenced by the eating habits of the parents (100\%), as well as eating habits of relatives and friends also affected by the level $<5 \%$ and $<9 \%$ respectively. This showed the fact that a child was introduced to foods on early of life by parents, especially mothers. The eating habits that will determine the level of nutrient consumption which then affected the BMI or nutritional status. This is supported by Sakamaki et al. (2005) who get similar results, that the eating habits, such as daily vegetable intake needs to be taken into account in measuring BMI.

\section{CONCLUSION}

Based on the results of the provided studies, it can be concluded that nutritional status evaluation method which based on measurements of adult body mass index (BMI) will result a more comprehensive outcomes if it was completed by internal and external factors data, such as nutrition knowledge, nutrition consumption, eating habits, and body composition (fat and body water). Indigenous wisdom of Indonesian people in food selection has an important role in nutrient consumption fulfillment, such as supplementation effect on rice and dried fish menu to increase the chemical score of protein, combination of ingredients in Indonesian cuisines such as tahu campur recipe which contained of beef soup served with green 
salad, mung bean sprouts, egg noodle, fried tofu, spiced fried cassava, garlic crackers and the sauce contained black shrimp paste and other selected traditional foods in daily consumption.

\section{ACKNOWLEDGEMENTS}

Authors would to thank to the Faculty of Agricultural Technology-Widya Mandala Surabaya

Catholic University which has provided funding of this research. In particular, our appreciation and thanks to all of the respondents for good cooperation, special thanks to the laboratory assistants and staff of Laboratory of Food Chemistry-Biochemistry and Nutrition of the academic year 2011/2012 by the implementation of technical support in this study.

\section{REFERENCES}

Abel Romero-Corral, MD, VK Somers, J Sierra-Johnson, RJ Thomas, KR Bailey, ML CollazoClavell, TG Allison, J Korinek, JA Batsis, and FL Jimenez. 2008. Accuracy of Body Mass Index to Diagnose Obesity in The US Adult Population. Int J Obes (Lond) 32: 959966.

Chouinard, L.E., DA Schoeller, AC Watras, RR Clark, RN Close, and AC Buchholz. 2007. Bioelectrical Impedance vs. Four-Compartment Model to Assess Body Fat Change in Overweight Adults. Obesity 15: 85-92

Ministry of Health of the Republic of Indonesia. , 1996. List of Food Composition. Directorate of Community Nutrition, Ministry of Health. $\triangle$

Ministry of Health. 2010. Basic Health Research Year 2010. Jakarta: Agency for Health Research and Development, Ministry of Health.

Hardinsyah and D Martianto., 1989. Assessment of the Adequacy of Energy and Protein and Quality Assessment of Food Consumption. Jakarta: Wirasari

Jebb, S.A., TJ Cole, D Doman, PR Murgatroyd, and AM Prentice. 2000. Evaluation of The Novel Tanita Body-Fat Analyser to Measure Body Composition by Comparison with a Four-Compartment Model. British Journal of Nutrition 83:115-122

Sakamaki,R., K Toyama, R Amamoto, Chuan-Jun Liu and N Shinfuku.2005. Nutritional Knowledge, Food Habits and Health Attitude of Chinese University Students-A cross Sectional Study. Nutrition Journal 2005, 4:4 doi:10.1186/1475-2891-4-4 
Shiwaku, K., E Anuurad, B Enkhmaa, A Nogi, K Kitajima, K Shimono, Y Yamane and T Oyunsuren. 2004. Overweight Japanese with Body Mass Indexes of 23.0-24.9 have Higher Risks for Obesity-Associated Disorders: A Comparison of Japanese and Mongolians. International Journal of Obesity 28: 152-158.

Soekatri, M. , 2011. Nutritional Status Assessment. In Balanced Nutrition in the Life Cycle (S Almatsier, Soetardjo S, and M Soekatri, Editors). Jakarta: PT Gramedia Pustaka Utama

Soetardjo, S. , 2011. Adult Nutrition. In Balanced Nutrition in the Life Cycle (S Almatsier, Soetardjo S, and M Soekatri, Eds). Jakarta: PT Gramedia Pustaka Utama

Wilson, ED.,Fisher, KH., and Garcia, PA. 1979. Principles of Nutrition. New York.: John Willey and Sons.

\section{ABOUT THE AUTHORS}

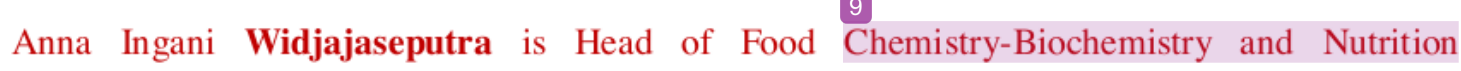
Laboratory, Faculty of Agricultural Technology, Widya Mandala Surabaya Catholic University.

The fields of her study is Food Chemistry and Food Nutrition, such as about sugar-starch balance during storage of sweet potatoes in varied temperature, moisture distribution of several starchy foods, role of tempering time and temperature on spring roll's wrapper characteristics, utilization of soybean tempe flour on additional food for children under of five years old. The scientific papers have been presented and published in International Seminar and journals. She gives lectures about Food Chemistry and Food Nutrition. She is a member of Indonesian Association of Food Technologist.

Theresia Endang Widoeri Widyastuti is Head of Food Quality Control and Sensory Evaluation Laboratory, Faculty of Agricultural Technology, Widya Mandala Surabaya Catholic University. She focuses on Food Chemistry and Human Nutrition researches. Development of functional food and drink based on papaya is her research focus. She has lecturing experience on functional foods for several years. She presented/published her researches in national journals or international seminars. She is a member of Indonesian Association of Food Technologist. Consulting and training on Food Quality Control, sensory evaluation and nutrition for food industry practicists and society are also her activities. 
1

Maria Matoetina Suprijono is a lecturer in Departement of Food Technology, Agricultural Technology Faculty, Widya Mandala Catholic University Surabaya. Her background is Community Nutrition and Food Science, She focuses her researches and teaching in Food Nutrition, Food Biochemistry, Nutrition Evaluation, Nutrients Formulation and Fortification. She is a member of Indonesian Association of Food Technologists.

1 Chatarina Yayuk Trisnawati is a lecturer in Department of Food Technology, Surabaya Widya Mandala Catholic University from 2003 until now. She is a member of Indonesian Association of Food Technologist. She has teaching experiences on beverage processing technology and bakery and cake technology for several years, as well on research, training and publication in area of beverage technology and bakery and cake technology

Note: the bold letters of authors name is surename 
ROLE OF INDIGENOUS WISDOM IN FOOD SELECTION: STUDY OF STUDENTS NUTRITIONAL STATUS OF FOOD NUTRITION PROGRAM-WIDYA MANDALA SURABAYA CATHOLIC UNIVERSITY

ORIGINALITY REPORT

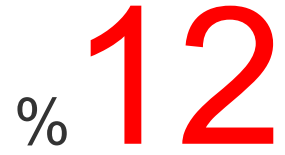

SIMILARITY INDEX

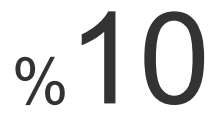

INTERNET SOURCES

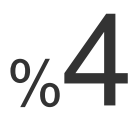

PUBLICATIONS

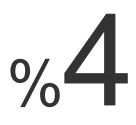

STUDENT PAPERS

PRIMARY SOURCES

1 spakten.net

Internet Source

$\% 5$

2 tasty-indonesian-food.com Internet Source

3 "Interfaces of Agriculture, Food Science and

Nutrition", Food and Nutrition Bulletin, 2018

Publication

4 Www.idosi.org

Internet Source

5 Submitted to University of North Carolina,

Greensboro

Student Paper

6 www.repository.wima.ac.id Internet Source

Selma Cvijetić, Irena Colić Barić, Slobodanka Bolanča, Vesna Jureša, Darinka Dekanić 
Ožegović. "Ultrasound bone measurement in children and adolescents", Journal of Clinical Epidemiology, 2003

Publication

8 hrcak.srce.hr

Internet Source

$<\% 1$

9 Submitted to Universitas Jenderal Soedirman Student Paper

$<\% 1$

10 insights.ovid.com

Internet Source

$<\% 1$

11

202.46.29.77

Internet Source

$<\% 1$

$\begin{array}{ll}\text { EXCLUDE QUOTES } & \text { ON } \\ \text { EXCLUDE } & \text { ON } \\ \text { BIBLIOGRAPHY } & \end{array}$

EXCLUDE MATCHES $<10$

WORDS 